\title{
Binding Studies and Effect of Light on the Conductance of Intercalated Curcumin into DNA
}

\author{
M. A. Subhan*, M. M. Islam, and M. R. U. Chowdhury \\ Department of Chemistry, Shah Jalal University of Science and Technology, Sylhet, Bangladesh.
}

Received 25 August 2011, accepted in final revised form 16 February 2012

\begin{abstract}
Curcumin is one of the most valuable ingredients for scientific research in view of medicinal and therapeutic importance. Curcumin is reported to have antitumor and anticancer activities. It can easily be extracted from Turmeric by solvent extraction methods. At first, dye was extracted through reflux and trituration process. Then curcumin was isolated from dye using column chromatography, which was investigated by infrared spectroscopy and melting point. Curcumin formed a complex with $\mathrm{Ce}^{3+}, \mathrm{Ce}\left(\mathrm{C}_{21} \mathrm{H}_{20} \mathrm{O}_{6}\right)_{\text {n, }}$, which was confirmed by comparing the IR spectrum of complex with that of ligand. We observed the effect of light on the curcumin intercalated into DNA and found that the electrons in curcumin excited by absorption of light and the conductance of the solution increased gradually when irradiated by UV-light. The result may indicate the electron conducting property of DNA in solution. We focused on the binding of curcumin with DNA. Our investigations also showed that both curcumin and $\mathrm{Ce}^{3+}$ complex have luminescence properties upon irradiation by UV-light.
\end{abstract}

Keywords: Curcumin; $\mathrm{Ce}^{3+}$-Complex; Luminescence; DNA; Antioxidant.

(c) 2012 JSR Publications. ISSN: 2070-0237 (Print); 2070-0245 (Online). All rights reserved.

doi: http://dx.doi.org/10.3329/jsr.v4i2.8482 J. Sci. Res. 4 (2), 411-418 (2012)

\section{Introduction}

Turmeric is a member of the curcuma botanical group, which is a part of the ginger family of herbs, the zingiberaceae. The root and rhizome (underground stem) of the curcuma longa plant is crushed and powdered into ground turmeric. Ground Turmeric is used as a source of curcumin for its therapeutic effect. Turmeric is an ancient spice and a traditional remedy that has been used as medicine, condiment and flavoring. Turmeric contains a variety of bioactive substances called curcumoids. The major curcumoids are curcumin, demethoxycurcumin and bis-demethoxycurcumin [1]. The most active component is curcumin. These substances comprise 3 to $6 \%$ of curcuma longa. Curcumin makes up 70 to $75 \%$ of the curcuminoids, demethoxycurcumin 15 to $20 \%$ and bis-demethoxycurcumin about 3\% [2].

\footnotetext{
*Corresponding author: subhan_che@yahoo.com
} 
Curcuminoids are obtained from turmeric by column (Silica gel, 20-270 mesh) extraction with dichloromethane. Curcumin is the most studied of the curcumoids. In its pure form, it is an orange-yellow crystalline powder that is insoluble in water. Its chemical name is (E, E)-1,7-bis (4-hydroxy-3-methoxyphenol)-1,6-heptadiene-3,5-dione. The structure of the curcumin was elucidated in 1910 and it was first known as diarylheptanoid [3]. The structures of curcumin in enol and keto forms are shown as:<smiles>COc1cc(/C=C/C(=O)/C=C(O)/C=C/c2ccc(O)c(OC)c2)ccc1O</smiles>

Enol form<smiles>COc1cc(/C=C/C(=O)CC(=O)/C=C/c2ccc(O)c(OC)c2)ccc1O</smiles>

Keto form

${ }^{13} \mathrm{C}$ NMR spectral data show that curcumin exists primarily in the enol form and not as the diketone. Curcumin exhibits a wide range of biological activities, e.g. anti-bacterial, anti-inflammatory, hypolipidemic, hepatoprotective, lipoxygenase, cycloxygenase, protease inhibitory effects, besides being effective active oxygen species scavengers and lipid peroxidase (a class of oxidoreductase enzymes) inhibitors [4, 5]. Curcumin and the curcuminoids also lower cholesterol, reduce platelet aggregation, inhibit proliferation of cancer cells and improve digestion by increasing the flow of bile from the gallbladder [6]. Extracts of curcuma longa rhizomes exhibit good preventive activity against carbon tetrachloride induced liver injury in vivo and in vitro. Curcumin inhibits intestinal gas formation by Clostridium perfringens at $0.05 \%$ concentration [7]. Its effect was evaluated at $0.005,0.013,0.025$ and $0.05 \%$ on gas formation by C. perfringen of intestinal origin. Gas formation decreased gradually as the curcumin concentration increased and there was no gas when curcumin concentration was $0.05 \%$, the level at which bacterial growth was inhibited completely. Oral administration of curcumin and curcuminoids (750 mg/kg) has been reported to prevent the formation and dissolution of urinary calculi. Turmeric powder extracts and curcumin also exhibit antioxidant property [8, 9].

Self-assembled dye-DNA network and its photo induced electrical conductivity have been investigated [10]. Design of successive ion conduction path in DNA films with ionic liquids has also been studied [11]. In our work we attempted to investigate the dye-DNA network and its photo induced electrical conductivity, because electrons in curcumin may be excited by absorption of UV-light and may influence the conductance of the system. 
There is a wide range of applications of fluorescence in the field of biochemistry and medicine. Large biological molecules can have a fluorescent chemical group attached by a chemical reaction, and the fluorescence characteristic of the attached tag enables very sensitive detection of the molecule. Aquarian, from the jellyfish Aequorea victoria, produces a blue glow in the presence of $\mathrm{Ca}^{2+}$ ions [12]. It has been used to image calcium flow in cells in real time. The success with aequorin spurred further investigation of $A$. victorria and led to the discovery of Green Fluorescent Protein (GFP), which has become an extremely important research tool. GFP and related proteins are used as reporters for many biological events including sub-cellular localization. Levels of gene expression are sometimes measured by linking a gene for GFP production to another gene. Binding and cleavage of DNA is at the heart of cellular transcription and translation, it is an obvious goal for therapeutic intervention and the development of diagnostic structural probes [13, 14]. In this paper, we report on the electrical properties, binding studies of intercalated curcumin into DNA and also the synthesis, characterization and luminescent properties of cerium-curcumin complex, $\mathrm{Ce}\left(\mathrm{C}_{21} \mathrm{H}_{20} \mathrm{O}_{6}\right)_{\text {n. }}$.

\section{Experimental}

\subsection{Dye extraction}

Ground turmeric (40 g) was crushed and mixed with dichloromethane (100 mL) in a conical flask, which was stirred with a magnetic stirrer on a hot plate. It was then transferred into a $500 \mathrm{~mL}$ round-bottom flask and heated to reflux for $2 \mathrm{~h}$. The mixture was filtered and the filtrate was concentrated in a hot water bath at $50^{\circ} \mathrm{C}$. The reddishyellow oily residue was triturated with hexane $(30 \mathrm{~mL})$. The resulting solid was collected by filtration. TLC analysis was carried out with preparative TLC plates coated with silica gel by using a solvent mixture (3\% methanol: $97 \%$ dichloromethane), which showed the presence of three components.

\subsection{Isolation of curcumin by column chromatography}

The crude material obtained after trituraion with hexane was dissolved in a minimum amount of $99 \%$ dichloromethane and $1 \%$ methanol $(\mathrm{v} / \mathrm{v})$ mixture and loaded on to a column packed with of silica gel (30 g). The column was eluted with the same solvent. Elutents were taken into various conical flasks successively, $5 \mathrm{~mL}$ in each case. Then TLC analysis was carried out for each collection. Some elute which was collected at the beginning of the elution process showed the presence of only one component. Other collections showed the presence of two components. The elutants, which showed the presence of only one component in TLC analysis, were collected and transferred into a $100 \mathrm{~mL}$ round-bottom flask and then evaporated in a rotatory evaporator to dryness. The melting point of the solid sample was found to be $165-169^{\circ} \mathrm{C}$. 


\subsection{IR analysis}

The IR spectrum of the isolated and dried curcumin $\left(\mathrm{C}_{21} \mathrm{H}_{20} \mathrm{O}_{6}\right)$ was recorded by SHIMADZU, IP Prestige-21, and FTIR Spectrophotometer with $\mathrm{KBr}$ pellet.

\subsection{Synthesis of $\mathrm{Ce}\left(\mathrm{C}_{21} \mathrm{H}_{20} \mathrm{O}_{6}\right)_{n}$ complex}

$0.001 \mathrm{M}$ solution of $\mathrm{Ce}\left(\mathrm{NO}_{3}\right)_{3}$ was prepared by dissolving $0.04342 \mathrm{~g}$ into $100 \mathrm{~mL}$ of absolute ethanol in a beaker. $0.003 \mathrm{M}$ solution of curcumin was prepared by dissolving $0.04416 \mathrm{~g}$ into $100 \mathrm{~mL}$ of absolute ethanol in a separate beaker. Then curcumin solution was added to metal solution slowly with stirring. Orange color precipitate formed was separated by filtration and air-dried. The IR spectrum of the complex was recorded.

\section{Results and Discussions}

\subsection{IR study of curcumin and $\mathrm{Ce}\left(\mathrm{C}_{21} \mathrm{H}_{20} \mathrm{O}_{6}\right)_{n}$}

Curcumin can form strong chelate with metal ions[15].There have been recent studies on metal complexes of curcumin[16]. We have synthesized $\mathrm{Ce}\left(\mathrm{C}_{21} \mathrm{H}_{20} \mathrm{O}_{6}\right)_{\mathrm{n}}$ and characterized by IR spectra. IR spectrum of curcumin, $\mathrm{C}_{21} \mathrm{H}_{20} \mathrm{O}_{6}$ showed peaks at $751 \mathrm{~cm}^{-1}$, which was due to $\mathrm{C}-\mathrm{H}$ deformation of disubstituted (ortho) aromatic ring; at $805 \mathrm{~cm}^{-1}$ for $\mathrm{C}-\mathrm{H}$ deformation of para disubstituted aromatic ring; at $958 \mathrm{~cm}^{-1}$ for C-H deformation of disubstituted (trans) alkene; peaks at $1072 \mathrm{~cm}^{-1}$ for C-O stretching of secondary alcohol; at $1122 \mathrm{~cm}^{-1}$ for $\mathrm{C}-\mathrm{O}$ stretching of ether; at $1278 \mathrm{~cm}^{-1}$ for $\mathrm{C}-\mathrm{O}$ stretching of $\mathrm{C}=\mathrm{C}-\mathrm{O}-\mathrm{C}$ group; at $1200 \mathrm{~cm}^{-1}$ for phenolic C-O stretching and $1457 \mathrm{~cm}^{-1}$ for alcohol C-O-H bending; at $1656 \mathrm{~cm}^{-1}$ for conjugation of double bond $\mathrm{C}=\mathrm{C}-\mathrm{C}=\mathrm{C}$ stretching and $1782 \mathrm{~cm}^{-1}$ for unsaturated ketone; at $2940 \mathrm{~cm}^{-1}$ for $\mathrm{C}-\mathrm{H}$ stretching in $\mathrm{CH}_{2}$; at $2969 \mathrm{~cm}^{-1}$ for $\mathrm{Ar}-\mathrm{H}$ stretching, at $2862 \mathrm{~cm}^{-1}$ for $\mathrm{C}-\mathrm{H}$ stretching of $\mathrm{C}-\mathrm{O}-\mathrm{CH}_{3}$ group. For the complex, $\mathrm{Ce}\left(\mathrm{C}_{21} \mathrm{H}_{20} \mathrm{O}_{6}\right)_{\mathrm{n}}$ the IR peaks observed were at $805 \mathrm{~cm}^{-1}, 1026 \mathrm{~cm}^{-1}, 1095 \mathrm{~cm}^{-1}, 1278 \mathrm{~cm}^{-1}$, $1734 \mathrm{~cm}^{-1}, 2343 \mathrm{~cm}^{-1}, 2358 \mathrm{~cm}^{-1}, 2862 \mathrm{~cm}^{-1}, 2923 \mathrm{~cm}^{-1}, 2970 \mathrm{~cm}^{-1}$ and $3740 \mathrm{~cm}^{-1}$. IR showed characteristic peaks for the curcumin ligand and $\mathrm{Ce}\left(\mathrm{C}_{21} \mathrm{H}_{20} \mathrm{O}_{6}\right)_{n}$ complex also showed similar IR spectra with shift in some peaks. A clear observation of the spectral changes in finger print region of $\mathrm{Ce}\left(\mathrm{C}_{21} \mathrm{H}_{20} \mathrm{O}_{6}\right)_{\mathrm{n}}$ complex compared to that of curcumin ligand also indicates the formation of $\mathrm{Ce}^{3+}$-complex.

\subsection{Effect of light on conductance of intercalated curcumin into DNA}

DNA was extracted from brinjal (Solanum Melongena) by solvent extraction method [17]. The intercalated curcumin into DNA was irradiated either by mercury lamp or tungsten filament bulb at room temperature to study the effect of light. A $30 \mathrm{~mL}$ solution of DNA was taken in a beaker and conductance was measured to be 0.018 . Curcumin solutions 
were then added, $1 \mathrm{ml}$ each time. After addition of $3 \mathrm{~mL}$ of curcumin solution, the solution was irradiated with UV-visible light. Results are shown in Figs. 1 and 2.

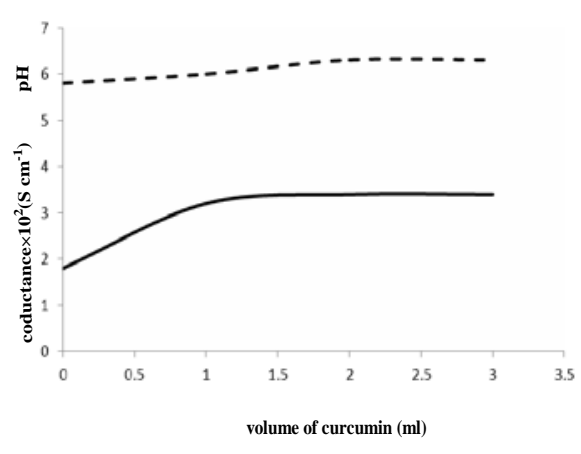

Fig. 1. Effect on conductance (-) and $\mathrm{pH}(\cdots \cdot \cdot)$ of the DNA solution due to the addition of $3 \mathrm{~mL}$ curcumin solution.

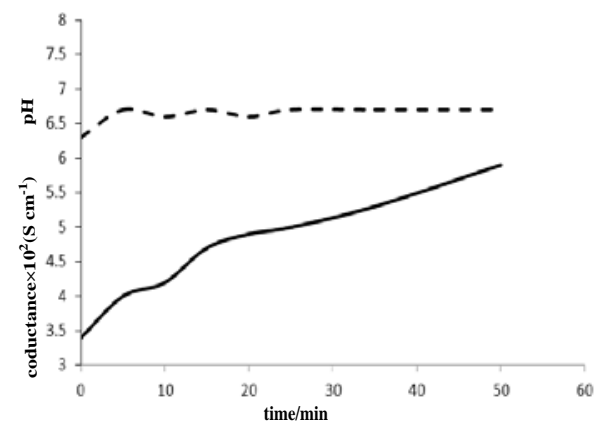

Fig. 2. Effect of light on the conductance (-) and $\mathrm{pH}(\cdots \cdot \cdot)$ of the solution of curcumin intercalated into DNA.

With the addition of curcumin into DNA solution up to $3 \mathrm{~mL}$, no or little change in $\mathrm{pH}$ and/or conductance were observed at around neutral $\mathrm{pH}$ values as shown in Fig. 1. While irradiation took place, an increase in conductance was observed with little or no change in pH values of the solution as shown in Fig. 2.

\subsection{DNA-curcumin binding studies}

DNA was extracted [17] from brinjal for the binding studies with curcumin. DNA contains four kinds of smaller building blocks or monomers called deoxyribotides or deoxyribonucleotides [18]. Hundreds of thousand of nucleotides are hooked to form a chain, and two chains are paired together and twisted into a double helix to form the finished DNA molecule. The interaction of the DNA and curcumin can be examined from the UV-Vis spectra (UV-Vis spectrophotometer, Model: UV-9100, China) of curcuminDNA intercalated complexes with the successive addition of curcumin. By monitoring the change in absorbance with increasing concentration of curcumin, the intrinsic binding constant can be evaluated by Eq. (1) $[19,20]$. The intrinsic binding constant, $K_{\mathrm{b}}$ was determined form the plot of [Cur] $/\left(\varepsilon_{\mathrm{a}}-\varepsilon_{\mathrm{f}}\right)$ vs [Cur] according to the equation (1) where [Cur] is the concentration of curcumin, $\epsilon_{\mathrm{a}}$, the apparent extinction coefficient is obtained by calculating $A_{\text {obsd }} /[\mathrm{DNA}], \epsilon_{\mathrm{f}}$ corresponds to the extinction coefficient of the DNA in its free form and $\epsilon_{\mathrm{b}}$ refers to the extinction coefficient of the curcumin-DNA complex in the fully bound form.

$$
[\operatorname{Cur}] /\left(\varepsilon_{\mathrm{a}}-\varepsilon_{\mathrm{f}}\right)=[\operatorname{Cur}] /\left(\varepsilon_{\mathrm{b}}-\varepsilon_{\mathrm{f}}\right)+1 / K_{\mathrm{b}}\left(\varepsilon_{\mathrm{b}}-\varepsilon_{\mathrm{f}}\right)
$$


Each set of data, gave a straight line with a slope of $1 /\left(\varepsilon_{\mathrm{b}}-\varepsilon_{\mathrm{f}}\right)$ and a $y$-intercept of $1 / K_{\mathrm{b}}\left(\varepsilon_{\mathrm{b}}-\varepsilon_{\mathrm{f}}\right) . K_{\mathrm{b}}$ was determined from the ratio of the slope to intercept. The absorbance of [DNA] solution was 0.080 and molar extinction coefficient of DNA solution, $\varepsilon$ was 6600 . According to Beer-Lambert law, $C=A / \varepsilon$, and the initial concentration of DNA solution was [DNA], $1.212 \times 10^{-5}$. By using Table 1 and Fig. 3 the intrinsic binding constant of DNA-curcumin complex, $K_{\mathrm{b}}$, was found to be 1.51 .

Table 1. Binding studies of curcumin with DNA.

\begin{tabular}{llllll}
\hline $\begin{array}{l}\text { Conc. of } \\
\text { curcumin } \\
\text { solution, } \\
\text { [Cur] }\end{array}$ & $\begin{array}{l}\text { Observed } \\
\text { absorbance of } \\
\text { DNA- } \\
\text { curcumin } \\
\text { solu. at } 420 \\
\text { nm }\left(A_{\text {obs }}\right)\end{array}$ & $\begin{array}{l}\text { Apparent } \\
\text { extinction } \\
\text { coeff. }\left(\varepsilon_{\mathrm{a}}\right) \\
=A_{\text {obs }} /[\mathrm{DNA} A\end{array}$ & $\begin{array}{l}\text { Extinction } \\
\text { coefficient } \\
\text { of the DNA } \\
\text { in its free } \\
\text { form }\left(\varepsilon_{\mathrm{f}}\right)\end{array}$ & $\left|\left(\varepsilon_{\mathrm{a}}-\varepsilon_{\mathrm{f}}\right)\right|$ & $\frac{[\text { Cur }]}{\left|\left(\varepsilon_{a}-\varepsilon_{f}\right)\right|}$ \\
\hline $3.2 \times 10^{-4}$ & 0.072 & 5940.60 & & 695.41 & $4.85 \times 10^{-7}$ \\
$2.4 \times 10^{-4}$ & 0.070 & 5775.57 & & 824.43 & $2.91 \times 10^{-7}$ \\
$1.6 \times 10^{-4}$ & 0.059 & 4860.87 & 6600 & 1739.13 & $0.92 \times 10^{-7}$ \\
$0.8 \times 10^{-4}$ & 0.019 & 1567.65 & & 5032.35 & $0.15 \times 10^{-7}$ \\
$0.4 \times 10^{-4}$ & 0.010 & 825.08 & & 5774.9 & $0.069 \times 10^{-7}$ \\
\hline
\end{tabular}

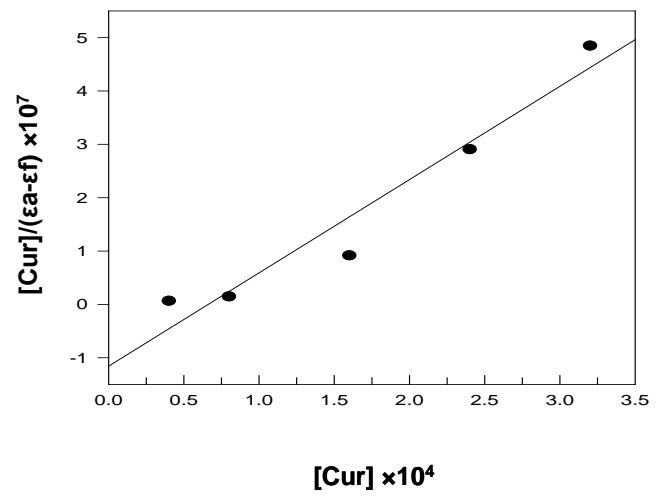

Fig. 3. A plot of $[\mathrm{Cur}] /\left(\varepsilon_{\mathrm{a}}-\varepsilon_{\mathrm{f}}\right) \times 10^{7}$ vs [Cur] $\times 10^{4}$ for curcumin intercalated with DNA.

\subsection{Curcumin: a potent complexing agent for metals}

The antioxidant activity of curcumin derivatives are greater than that of vitamin E, and particularly identical to that of curcumin in a Fe(II)-linoleic acid peroxidation test. Curcumin is a very intresting substance because it generates phototoxic oxidizing species including $\mathrm{HO} \cdot$ and $\mathrm{H}_{2} \mathrm{O}_{2}$, when exposed to light, but it also protects against lipid peroxidation as radical scavenger [21]. This compound is a potent complexing agent for 
metal ions such as iron (III) [21], it can acts as phototoxicant and protective agent. Curcumin, like other $\beta$-diketones, exists partly in the enol form, which may also help to explain many of its unusual anti- and prooxidant properties [21]. Curcumin forms a complex with cerium, $\mathrm{Ce}\left(\mathrm{C}_{21} \mathrm{H}_{20} \mathrm{O}_{6}\right)_{\mathrm{n}}$, whose structure was confirmed by comparing the IR spectrum of both complex and ligand in solid form. Curcumin is a $\beta$-diketone, can act as uninegative bidented ligand. Coordination number of $\mathrm{Ce}^{3+}$ would be eight, but for the formation of neutral complex and also because of the bulky substituent in the curcumin, in the complex, $\mathrm{Ce}\left(\mathrm{C}_{21} \mathrm{H}_{20} \mathrm{O}_{6}\right)_{n}, n=3$ might be suitable for complexation.

\subsection{Luminescent properties of curcumin and its metal complex}

When irradited with UV-light, a mercury lamp at $380 \mathrm{~nm}$ both curcumin (orange) and Ce $\left(\mathrm{C}_{21} \mathrm{H}_{20} \mathrm{O}_{6}\right)_{n}$ (deep orange) showed green fluorescence emission in $\mathrm{CH}_{2} \mathrm{Cl}_{2}$ solution at room temperature, which is disappeared when removed from light source. Both curcumin and $\mathrm{Ce}^{3+}$ complex had luminescence properties. It was clearly observed that the fluorescence is greatly enhanced when $\mathrm{Ce}^{3+}$ formed a complex with curcumin.

\section{Conclusion}

Yellow dye was extracted from dried turmeric herb and curcumin was separated from this dye and characterized by IR and UV-visible spectra. Complex of curcumin with cerium, $\mathrm{Ce}^{3+}$ may be used for medicinal purpose. Intercalated curcumin into DNA showed conductivity when irradiated either by mercury lamp or tungsten filament bulb at room temperature. This may be due to the conducting DNA-curcumin solution. Binding studies of curcumin with DNA was performed to calculate binding constant, $K_{\mathrm{b}}$, which was found to be 1.51 . This might be an important parameter for the application of DNA-curcumin intercalated compound in medicine. The cerium-curcumin complex has enhanced luminescence; showed green luminescence upon UV-irradiation in solution at room temperature.

\section{References}

1. S. Gilda, M. Kanitkar, R. Bhonde, and A. Paradkar, LWT- Food Sci. Technol. 43, 59 (2010).

2. T. J. Zachariah, Indian Spices and Exploration of Its Intrinsic Quality: http://www.biocircle-project.eu/media/7080/dr_john_z_calicut.pdf

3. A. M Anderson, M. S. Mitchell, and R.S. Mohan, J. Chem. Edu. 77, 359 (2000). http://dx.doi.org/10.1021/ed077p359

4. V. P. Menon and A. R. Sudheer, Adv. Exp. Med Biol. 595, 105 (2007). http://dx.doi.org/10.1007/978-0-387-46401-5_3

5. A. K. Tuba and I. Gülçin, Chemico-Biological Interactions, 174, 27 (2008). http://dx.doi.org/10.1016/j.cbi.2008.05.003

6. R. Wilken, M. S.Veena, M. B. Wang, and E. S. Srivatsan, Molecular Cancer 10 (12), 1 (2011). PMid:21205300; PMCid:3024301

7. B. B. Aggarwal, Y-J. Surh, and S. Shishodia, Advances in Experimental Medicine and Biology (Springer, New York, 595, 2007). 
8. N. K. Khanna, Current Sci. 76, 1351 (1999).

9. A. K. Nadkarni, Indian Materia Medica (Popular Prakashani, Bombay, 1976).

10. G. Jianhu, T. Shinnichi, O. Youchi, T. Hitoshi, and K. Tomoji, Appl. Phys. Lett. 80, 688 (2002). http://dx.doi.org/10.1063/1.1435805

11. N. Naomi and O. Hiroyuki, J. Mater. Chem. 12, 2299 (2002). http://dx.doi.org/10.1039/b202972c

12. F. Prendergast and K. Mann, Biochemistry 17, 3448 (1978). http://dx.doi.org/10.1021/bi00610a004

13. R. Tsien, Annu.Rev. Biochem. 67, 509 (1998). http://dx.doi.org/10.1146/annurev.biochem.67.1.509

14. L. J. Boerner and J. M. Zaleski, Curr. Opin. Chem. Biol. 9, 135 (2005). http://dx.doi.org/10.1016/j.cbpa.2005.02.010

15. M. Borsari, E. Ferrari, and R. Grandi, Inorg. Chim. Acta, 328, 61 (2002). http://dx.doi.org/10.1016/S0020-1693(01)00687-9

16. Y. M. Song, J. P. Xu, L. Ding, Q. Hou, J. W. Liu, and Z. L. Zhu, J. Inorg. Biochem. 103, 396 (2009). http://dx.doi.org/10.1016/j.jinorgbio.2008.12.001

17. M. A. Subhan, M. K. H. Rashed, B. Ahmed, and M. R. U. Chowdhury, Proc. Pakistan Acad. Sci. 45, 171 (2008).

18. P. S. Verma and V. K. Aggarwal, Cell Biology, Genetics, Molecular Biology, Evolution as well as Ecology, 4th Edition (S. Chand \& Company Ltd., New Delhi, 2005).

19. H. L.Chan, H. Q. Liu, B. C. Tzeng, Y.S. You, S.M. Peng, M. Yang, and C. M. Che, Inorg. Chem. 41, 161 (2002). http://dx.doi.org/10.1021/ic0112802

20. S. Arounaguiri, D. Easwaramoorthy, A. Ashokkumar, A. Dattagupta, and B. G. Maiya, Proc. Indian Acad. Sci. 112, 1 (2000). http://dx.doi.org/10.1007/BF02704295

21. A. L. Richard, Naturally occuring antioxidants (Lewis Publishers, New York, 1997). 